\section{Literature review}

Volumen 32(1):326-337. Enero-abril, 2021

e-ISSN 2215-3608, doi:10.15517/am.v32i1.40896

http://www.revistas.ucr.ac.cr/index.php/agromeso

\title{
The RNAi as a tool to control tropical pathogens ${ }^{1}$
}

\section{EI ARNi como una herramienta para el control de patógenos tropicales}

\author{
Alejandro Hernández-Soto², Fabián Echeverría-Beirute ${ }^{3}$ Tomás Guzmán-Hernández ${ }^{3}$
}

1 Reception: 4 de marzo, 2020. Acceptance: 20 de julio, 2020. This work was part of the Doctoral Thesis of the first author, Doctorado en Ciencia Naturales para el Desarrollo (DOCINADE), Instituto Tecnológico de Costa Rica, Universidad Nacional, Universidad Estatal a Distancia, Cartago, Costa Rica, and financed by the Project "Producción de mutantes de arroz (Oryza sativa) tolerantes a herbicidas utilizando rayos gamma para contribuir con el manejo sostenible del cultivo". Vice-Rectory for Research of thel Instituto Tecnológico de Costa Rica.

2 Instituto Tecnológico de Costa Rica, Biology School, Biotechnology Research Center. Costa Rica. alhernandez@itcr.ac.cr (corresponding author, https://orcid.org/0000-0001-9435-5117).

3 Instituto Tecnológico de Costa Rica, sede San Carlos. Apartado postal 159-7050, Florencia, Alajuela, Costa Rica. Tel: (506) $2475-5310$. fecheverria@itcr.ac.cr (http://orcid.org/0000-0002-7238-220X); tjguzman@itcr.ac.cr (https://orcid.org/0000-0002-2719-8550).

\begin{abstract}
Introduction. Sustainable farming requires new tools for the control of pathogens, since there is a constant evolution to overcome the current biological and chemical strategies. The information provided by the transcriptomics allows creating new possibilities to tackle the pathogens. It is possible to interrupt the genetic expression of a pathogen and disable it using RNA interference (RNAi). Objective. To perform an analysis of an emerging technology useful for pest control, based on RNA interference. Development. Sustainable farming is measured based through social, economic, and environmental indicators. A key indicator of agriculture is the decrease in inputs for the control of pathogens and the increase in their specificity. Pest control mechanisms based on RNA interference meet both parameters. RNAi is known to have at least two functions, first for gene expression regulation, and secondly as a defense mechanism against pathogens. Consequently, RNAi can be used to protect crops from pathogens by developing genetically modified plants, or by the external application form of an aerosol. The RNAi aerosol is a tool that relies on inactivating the pathogen genes and can complement other agronomic tools available for this purpose. It is possible to design RNAi against tropical pests based on published transcriptomes, although it is necessary to overcome limitations regarding design, degradation, and stability. Conclusion. Interference RNA methods have the potential to be useful tools to control tropical pathogens as an alternative to achieve sustainable farming.
\end{abstract}

Keywords: sustainable farming, biotechnology, aerosol RNAi.

\section{Resumen}

Introducción. La agricultura sostenible requiere de nuevas herramientas para el control de patógenos, dado que existe una constante evolución para sobrepasar las estrategias biológicas y químicas que se usan actualmente. La información derivada de los transcriptomas permite crear nuevas posibilidades para controlar a los patógenos. Es posible interrumpir la expresión genética de un patógeno e inhabilitarlo mediante ARN de interferencia (ARNi). 
Objetivo. Realizar un análisis de una tecnología emergente, útil para el control de plagas, basados en ARN de interferencia. Desarrollo. La producción agrícola sostenible se mide internacionalmente mediante indicadores sociales, económicos y ambientales. Uno de los indicadores clave de la agricultura es la disminución de insumos para el control de patógenos y el aumento de la especificidad de los mismos. Los mecanismos de control de plagas basados en ARN de interferencia cumplen ambos parámetros. El ARNi tiene al menos dos funciones, la primera es de regulación de la expresión genética y la segunda es servir de mecanismo de defensa contra patógenos. El ARNi se puede usar para la protección de los cultivos mediante el desarrollo de plantas genéticamente modificadas, o mediante la aplicación externa en forma de aerosol. El aerosol de ARN de interferencia es una herramienta que se basa en inactivar los genes del patógeno y puede ser un complemento a las herramientas agronómicas disponibles. Es posible diseñar ARNi para plagas tropicales sobre la base de los transcriptomas publicados, aunque es necesario sobrepasar limitaciones de diseño, degradación y estabilidad para ello. Conclusión. Los métodos de control mediante ARN de interferencia tienen el potencial de constituirse herramientas útiles para controlar los patógenos tropicales como una alternativa para sistemas de producción más sostenibles.

Palabras clave: agricultura sostenible, biotecnología, ARN en aerosol.

\section{Introduction}

Brundtland's report in the 80s set the bases for sustainable food production systems. The model evolved into an integrated environment, the social and the economic approach, measured into indicators (Latruffe et al., 2017). Specifically in the case of farming, indicators must include the plan to control plant pests and pathogens (Lebacq et al., 2013). Examples of such evaluations are widely described by models such as Response-Inducing Sustainability Evaluation (RISE) (Schindler et al., 2015), Sustainability Assessment of Food and Agriculture Systems (SAFA) (Food and Agricultural Organization, 2014), Public Goods Tool (PG), and Indicateurs de Durabilité des Exploitations Agricoles (IDEA). All models agreed that the use of chemical inputs must comply with best farming practices and sometimes decreased in quantity, toxicity, or application volume. However, there are cases where there is no other alternative to control pests. The objective of this work was to perform an analysis of an emerging technology useful for pest control, based on RNAi.

\section{What is RNA interference or RNAi?}

RNAi was first reported in 1998 as a tool to externally cause gene silencing in the nematode Caenorhabditis elegans by applying an injection of double-stranded RNA (Fire et al., 1998). The discovery won the Nobel Prize in Physiology or Medicine in 2006 (The Nobel Prize in Physiology or Medicine, 2006). A RNAi results when a 20-30 RNA sequence is recognized by a piece of specialized protein machinery named Argonaut, to block or interfere with another RNA molecule (Castel \& Martienssen, 2013). The RNAi machinery is used by the eukaryote cells with two different roles (Figure 1): 1) the first is named miRNA and is mainly used to regulate gene expression, and 2) the second is named siRNA and works as a defense system able to detect and inactivate pathogenic RNAs such as virus sequences (Hudzik et al., 2020; Rosa et al., 2018; Wilson \& Doudna, 2013).

The miRNA system is aimed at self-control gene expression and is not usually related to the control of pathogens. miRNA start with a genomic sequence or MIR loci (Papp et al., 2003) that is used as a template to produce a first double-stranded RNA synthesized by RNA polymerase II at the nucleus. The resulting RNA fragment is named primiRNA and is subsequently processed into another molecule, pre-microRNA, by an enzymatic complex of Drosha 


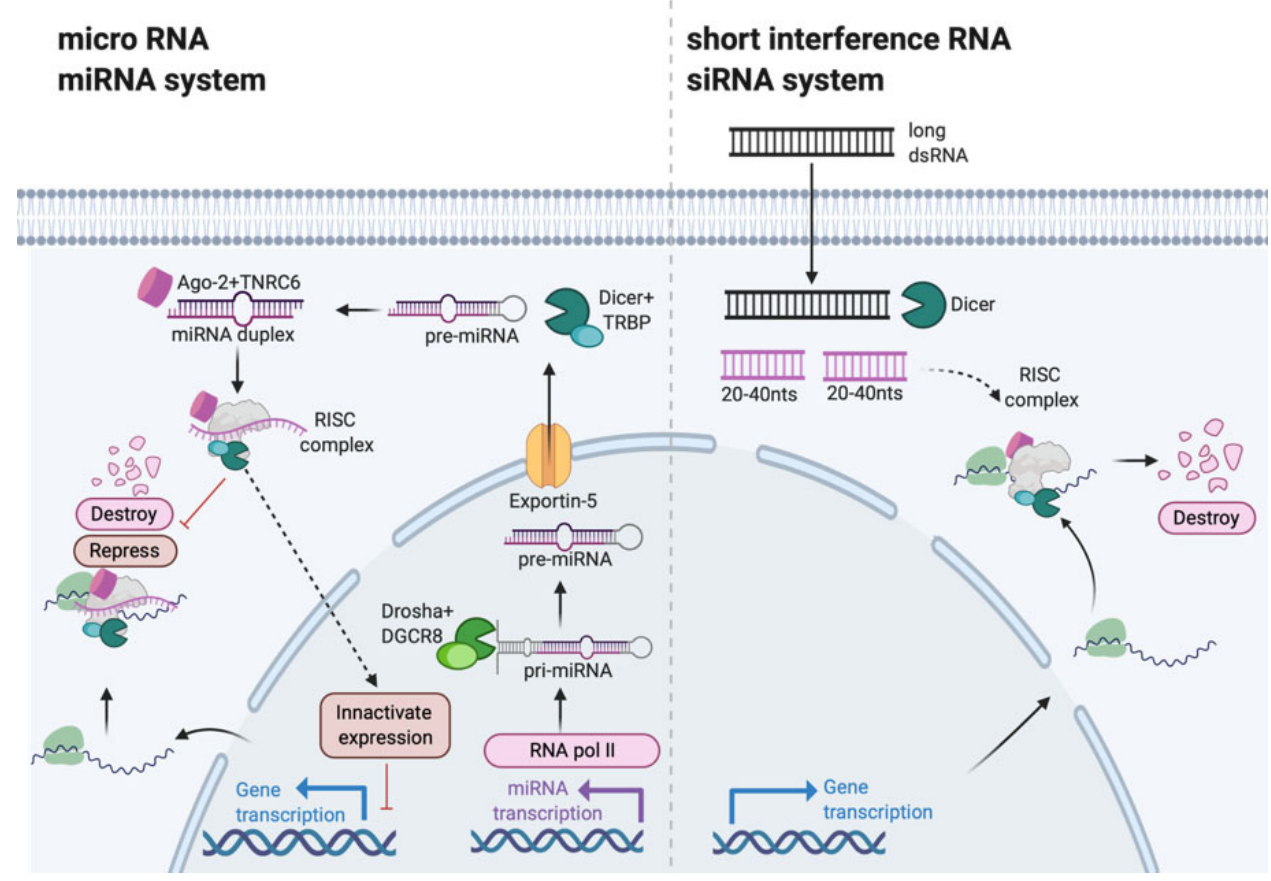

Figure 1. Schematic representation of the RNAi systems, microRNA and siRNA. Note that miRNA is mostly used to regulate, repress, destroy, and inactivate internal gene expression, while the siRNA system reacts by destroying complementary RNA molecules and usually responds to a viral dsRNA. Created with BioRender.com

Figura 1. Representación esquemática de los sistemas de ARNi microARN y siRNA. Obsérvese que el miARN se utiliza principalmente para regular, reprimir, destruir e inactivar la expresión génica interna, mientras que el sistema de siARN reacciona destruyendo las moléculas de ARN complementario y suele responder a un dsARN viral. Creado con BioRender.com

and DGCR8. Next, the processed RNA is exported by Exportin-5 outside the nucleus into the cytoplasm. Once in the cytoplasm, the pre-microRNA binds a Helicase resulting in a single-stranded sequence. The single-stranded RNA can now bind to the enzymatic complex named RNA - induced silencing complex (RISC) and composed by at least Dicer + TRBP Tar RNA binding protein 2, ARGONaute + TRNC6. The complex can finally target and repress the expression of a gene by capturing a messenger RNA without destroying it or can inactivate the genomic sequence by methylation (Axtell, 2013; Guo et al., 2016; Rosa et al., 2018; Wilson \& Doudna, 2013) miRNA can also silence pathogens gene expression as described next.

\section{The role of the siRNA system}

Short interference RNA (siRNA) systems work similarly to miRNA system, but instead of being used for their gene expression control, this process act as a defense system against pathogens (Muthamilarasan \& Prasad, 2013). Plants use siRNA to fight viral RNAs. For example, Arabidopsis generates a 21 and 24 nucleotide virus specific siRNA when it is infected with Tobacco rattle virus (TRV), as well as a 21 nucleotide specific siRNA when infected with Turnip crinkle virus (TCV) (Waterhouse \& Fusaro, 2006). The defense complex is composed of two 
parts: Dicer and the RNA. Dicer is an RNase III enzyme that works with the 21-23 bp RNA duplexes to form the so-called small interfering RNAs (siRNAs). The enzyme RISC processes the siRNAs and separates one of the two RNA strands. The final product is an active RISC with an antisense RNA that can match the enzyme Argonaute, that can now join the antisense RNA and cleavage the alien mRNA (Kaur et al., 2016). When a double-stranded RNA (dsRNA) is applied externally, it can trigger the siRNA system with the same results by targeting or inactivating the complementary gene expression of the cell in organisms such as Caenorhabditis elegans (Fire et al., 1998).

In the case of plants, RNA interference is present in both directions: the pathogens and host plants, in a phenomenon named cross-kingdom RNAi. They are both, plants and pathogens, provided with siRNAs to target genes of their counterparts for silencing (Zhao et al., 2018) as described next.

Pathogens like the fungi Botrytis cinerea produce RNA to knock down the plant defense system. When the B. cinerea genes $d c l l$ and $d c l 2$ are broken, the strain has reduced virulence (Weiberg et al., 2014). On the other hand, plants are also provided with a system to defend themselves against pests in a cross-kingdom RNAi. Plants can use the system against bacteria, fungi, oomycetes, and can also take external RNAi for their defense against a pathogen (Cai et al., 2018a).

RNAi is now recognized as a Trojan Horse of the plant kingdom because the plant delivers vesicles charged with RNAi into the attacking fungi (Castillo-González \& Zhang, 2018). External vesicles are relevant keys in the RNAi interaction process (Rutter \& Innes, 2018). Plants can secrete RNA vesicles at the specific site of infection throughout the exosomes, where the proteins TET8 and TET9 are key in the process. For example, Arabidopsis secretes siRNAs TAS1c-siR483 and TAS2-siR453 into the fungal cells of $B$. cinerea. The first one targets the BC1G_10728 and BC1G_10508 gene expression. BC1G_10728 expression results in a vacuolar protein sorting 51 (Bc-Vps51) that seems to be key to virulence. BC1G_10508 expression results in a large subunit of the complex Bc-DCTN1 that is in charge of vesicle trafficking. The second siRNA targets BC1G_08464, related to membrane trafficking (Cai et al., 2018b). In the same way, miR166 and miR159 are produced in cotton when infected with the fungi Verticillium dahliae and transported precisely to the fungi to target the genes Clp- 1 and Hic-15 respectively, resulting in reduced virulence (Zhang et al., 2016). In addition, although miRNA161 and miRNA173 are related to Arabidopsis plant's defense against Phytophthora infections triggered by a pattern recognition receptor, the pathogen also fights against the RNAi mechanism by encoding an RNAi suppressor (Hou et al., 2019).

\section{How can RNAi be used to control tropical pathogens?}

RNAi can be used to protect crops from pathogens by developing genetically modified plants or by externally spraying dsRNA (Figure 2). The first example of a commercially used genetically modified plant that resists a virus was the famous Rainbow Hawaii papaya, resistant to the papaya ringspot virus (Gonsalves et al., 2010). Genetically modified plants that do have siRNA are known as Host-Induced Gene Silencing (HIGS) and can defend themselves against viruses, nematodes, and bacteria (Nunes \& Dean, 2012).

The external application or spray dsRNA triggers the RNAi system creating a pest-specific control method. Such application is becoming an important global trend in the use of novel biopesticide (Table 1) (Mat-Jalaluddin et al., 2019). The external RNAi is known to be useful to control pests such as nematodes (Koch \& Kogel, 2014; Lilley et al., 2012), arthropods such as Drosophila melanogaster, Tribolium castaneum (Yu et al., 2013), fungi such as Sclerotinia sclerotiorum and B. cinereal (McLoughlin et al., 2018b), and aphids such as the pea aphid Acyrthosiphon pisum and Greenbug Schizaphis graminum, targeting in both cases the salivary protein C002 (Yu et al., 2016). For example, the topical application of dsRNA to the surface of barley (Hordeum vulgare L.) leaves resulted in reduced growth of the pathogen Fusarium graminearum. In this case, the dsRNA targets the genes of fungal cytochrome P450, lanosterol and C-14 $\alpha$ demethylases. All of them required for fungal ergosterol biosynthesis and resulted in $50 \%$ decrease of the corresponding transcript (Koch et al., 2016). Long dsRNA require 

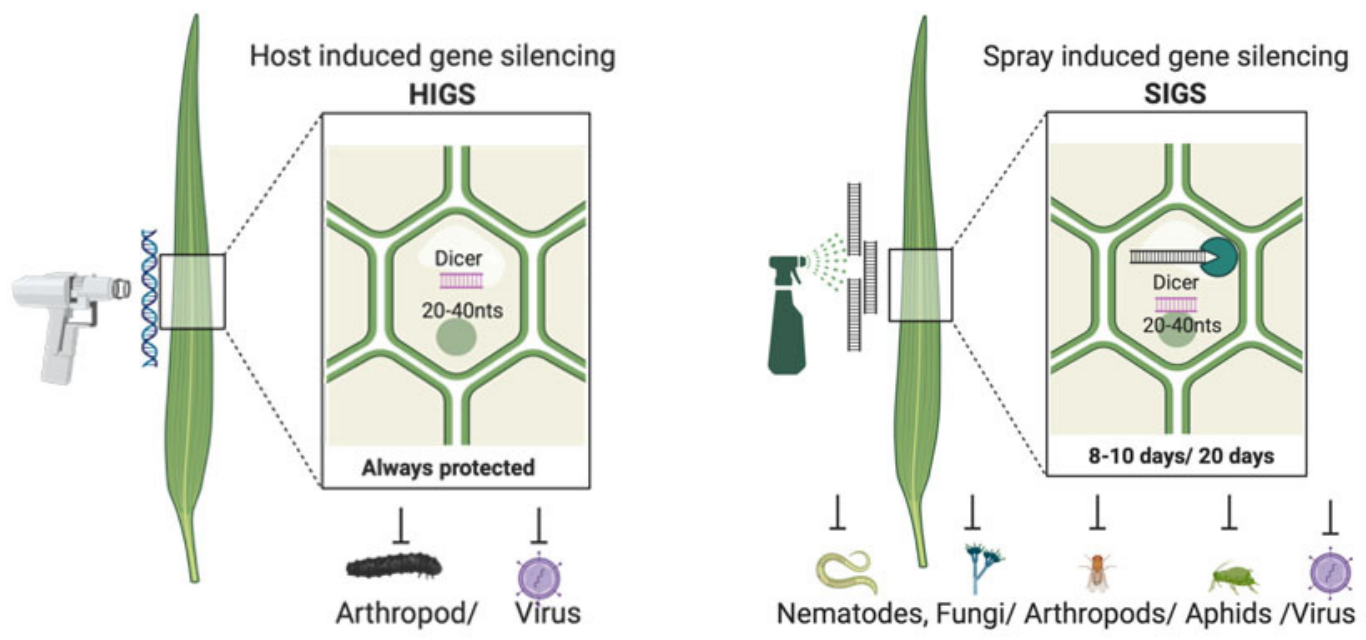

Figure 2. RNAi strategies to control tropical pathogens: (A) Host induced gene silencing (HIGS) and (B) Spray induced gene silencing (SIGS). Created with BioRender.com

Figura 2. Estrategias de ARNi para controlar los patógenos tropicales: A) Silenciamiento de genes inducido por el huésped (HIGS) y B) Silenciamiento de genes inducido por spray (SIGS). Creado con BioRender.com

processing by internal fungi Dicer like protein 1 (DCL1) in order to be active (Koch et al., 2016; Wang et al., 2016a; Wang \& Jin, 2017). Another example was with the fungi Botrytis cinerea using dsRNA targeting DCL1 and DCL2 simultaneously (Wang et al., 2016b). Double-stranded RNA can become an important tool in the control of both Sclerotinia sclerotiorum and Botrytis cinerea fungi (McLoughlin et al., 2018b).

The spray of dsRNA on plant surfaces, so-called SIGS (spray-induced gene silencing), is also a powerful tool because it has proven to confer efficient crop protection against viruses (Wang \& Jin, 2017). It is important to note that sprays of long dsRNA are capable of getting into the vascular plant system and also into pathogens such as fungi (Koch et al., 2016; Song et al., 2018). RNAi can move between cells through plasmodesmata and vascular bundles, and be used in exosomes for defense (Figure 3) (Cai et al., 2018a; Castillo-González \& Zhang, 2018; Reagan et al., 2018). Furthermore, this new generation of RNA fungicides can last for 8-10 days when spraying directly to plants (Wang et al., 2016b), and above 20 days when using clay particles (Mitter et al., 2017). The exogenous application of dsRNA is also able to suppress plant's genes and provoke methylation of homolog sequences (Dubrovina et al., 2019).

It is also important to note that the Organisation for Economic Cooperation and Development (OECD) had a conference on RNA interference (RNAi)-based pesticides concluding the safety of RNAi, based on the history of safe consumption of naturally occurring dsRNA in food and feed (Rodrigues \& Petrick, 2020). The environmental impact of RNAi would also be low, since there is low potential for persistence in the environment including soil, sediment, and surface water compartments (Parker et al., 2019; Bachman et al., 2020).

SIGS faces three challenges: degradation, stability, and design of the RNAi. RNAi degradation depends on the target pest. For example, Lygus lineolaris and Schistocerca gregaria are both provided with RNA degrading enzymes or ribonucleases. It means that when applying the external double-stranded RNAs, it is degraded in their guts and consequently inactivates any response (Allen \& Walker, 2012). Moreover, the protein StauC present in coleopterans is key to RNAi, which seems to be related to the intracellular trafficking of dsRNA (Yoon et al., 2018). RNAi efficacy will rely on the enzymatic degradation of the target organism (Wang et al., 2016a; Guan et al., 2018). 
Table 1. dsRNA causing gene suppression or lethality in multiple species.

Cuadro 1. dsARN que causa la supresión de genes o la letalidad en múltiples especies.

\begin{tabular}{|c|c|c|c|}
\hline Organism & Target genes or sequences & Comments & Reference \\
\hline Caenorhabditis elegans & $\begin{array}{l}\text { unc-22. ref. 9, unc-54, ref.12, } \\
\text { fem-1, ref.14, and hlh-1, ref.15, } \\
\text { nuclear-localized GFP }\end{array}$ & $\begin{array}{l}\text { First report of RNAi, Mimics loss- } \\
\text { of-function mutation }\end{array}$ & (Fire et al., 1998) \\
\hline Globodera pallida & $\begin{array}{l}\text { FMRFamide-like peptides } \\
\text { (FLPs), flp- } 1,-6,-12,-14 \text {, or }-18 \text { ) }\end{array}$ & $\begin{array}{l}\text { Caused severe effects on nematode } \\
\text { migration }\end{array}$ & (Kimber et al., 2007) \\
\hline Meloidogyne incognita & $\begin{array}{l}\text { Signal peptidase complex of the } \\
\text { nematode cau }\end{array}$ & $\begin{array}{l}\text { Soaking } M \text {. incognita with dsRNA } \\
\text { resulted in reduction in established } \\
\text { nematodes at } 14 \text { days post infection. }\end{array}$ & (Charlton et al., 2010) \\
\hline Meloidogyne artiellia & chitin synthase & delay in the hatching of juveniles & (Fanelli et al., 2005) \\
\hline Radopholus similis & Xylanase & reduced infection & (Haegeman et al., 2009) \\
\hline Fusarium graminearum & $\begin{array}{l}\text { Ergosterol biosynthesis genes } \\
\text { (CYP51A, CYP51B, CYP51C), }\end{array}$ & $\begin{array}{l}\text { Barley leaf tissue sprayed with a } \\
791 \text { nt long dsRNA (CYP3-dsRNA) } \\
\text { efficiently inhibited the necrotrophic } \\
\text { fungus Fusarium graminearum }\end{array}$ & (Koch et al., 2016) \\
\hline Botrytis cinerea & DCL1 and DCL2 & inhibits gray mold disease & (Wang et al., 2016b) \\
\hline Tribolium castaneum & EGFP & $\begin{array}{l}\text { It contains a systemic RNAi } \\
\text { response. A } 520 \mathrm{bp} \text { fragment works } \\
\text { better than a } 69 \mathrm{bp} \text {. A higher } \\
\text { concentration }\left(4 \mathrm{ug} \mathrm{ul}^{-1}\right) \text { works } \\
\text { better than lower }\left(1 \mathrm{ug} \mathrm{ul}^{-1}\right)\end{array}$ & (Miller et al., 2012) \\
\hline Acyrthosiphon pisum & salivary protein $\mathrm{C} 002$ & $\begin{array}{l}\text { RNAi injection resulted in reduced } \\
\text { life-span }\end{array}$ & (Mutti et al., 2006) \\
\hline Schizaphis graminum & salivary protein $\mathrm{C} 002$ & $\begin{array}{l}\text { RNAi was provided in an artificial } \\
\text { diet and resulted in lethality }\end{array}$ & (Zhang et al., 2015) \\
\hline
\end{tabular}

In regard to stability, the technique has been improved to last longer. With the use of clay particles of 45 nanometers in diameter, a resulting 20-days protection against viruses has been specifically shown in the case of the plants Vigna unguiculata ssp. unguiculata (cowpea) and Nicotiana tabacum cv. xanthi against the virus pepper mild mottle virus (PMMoV) and cucumber mosaic virus (CMV) strain 20740 (Mitter et al., 2017). Another strategy to address an enhanced response, could also be in formulations such as nanoparticles of chitosan (Mysore et al., 2013; Dhandapani et al., 2019) or guanylate polymers (Christiaens et al., 2018). Furthermore, a protein capsid such as virus-like particles (VLPS) can be linked to the dsRNA to stabilize it, avoid degradation, and allowing further purification (Fang et al., 2017). The technology is already available and is being used to control insects such as ants by RNAgri. SynBio strategies such as using bacteriophage phi6 to increase stability are also an option (Niehl et al., 2018). Another stability limitation of SIGS is the dependence of external application in absence of an internal mechanism of amplification, resulting in protection for about 8-days in the case of Triticum aestivum sprayed with 400 ng dsRNA targeting Myo5 gene of Fusarium asiaticum (Song et al., 2018).

The design of the dsRNA is also an important variable to consider since long dsRNA results in better efficiency compared with siRNA in Tribolium castaneum (Yoon et al., 2018). Long dsRNA (200-500nts) also works better in controlling Fusarium targeting cyp51 genes (Höfle et al., 2020). The design can be achieved by studying the genome of the target pest (Wang et al., 2011), and it can be chemically synthesized allowing a first testing analysis 


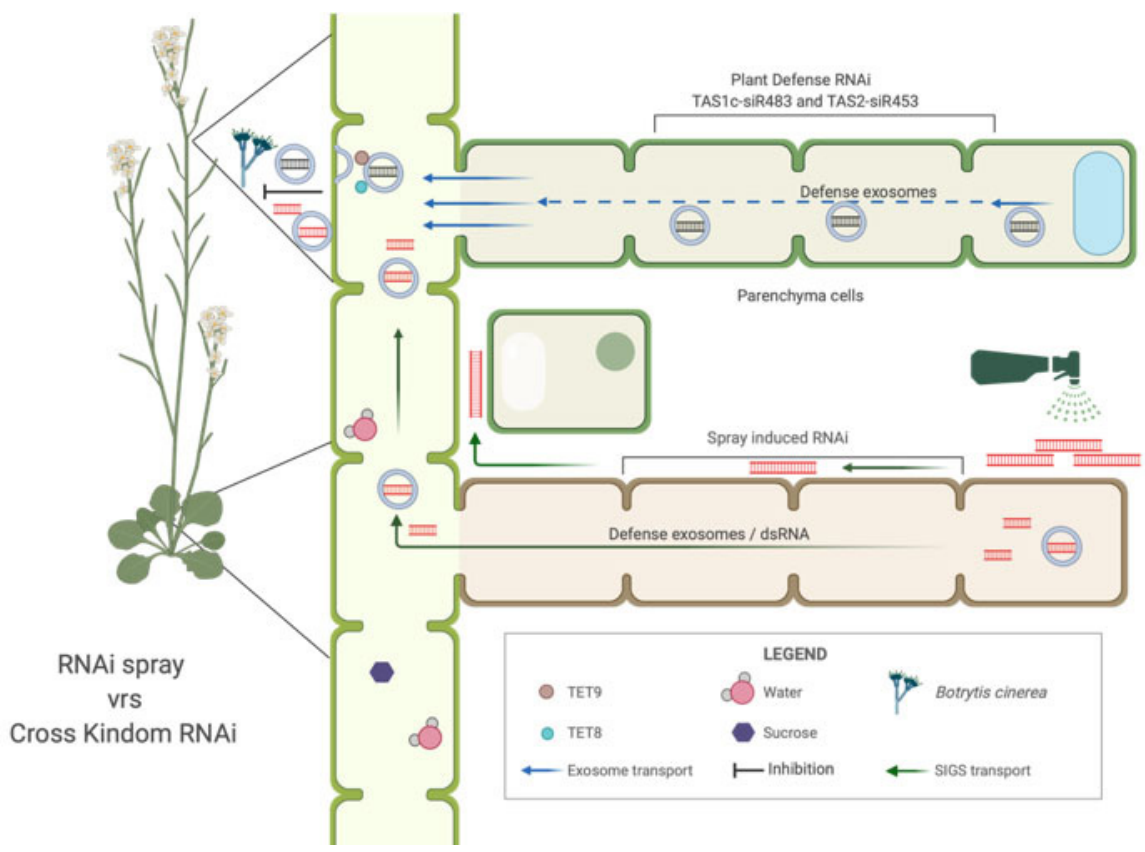

Figure 3. RNAi mobilization in the vascular plant system. RNAi can move between cells through plasmodesmata and the vascular bundle and be used in exosomes for defense against pathogens. Note the protein TET9 and TET8 key in the exosome defense mobilization. Created with BioRender.com.

Figurea 3. Movilización de ARNi en el sistema vascular de la planta. El ARNi puede moverse entre las células a través de los plasmodesmatos y el haz vascular y ser usado en los exosomas para la defensa contra los patógenos. Obsérvese la proteína TET9 y TET8, clave en la movilización de la defensa del exosoma. Creado con BioRender.com.

or proof of concept (Genolution Inc., Seoul, Republic of Korea). Therefore, the selection of gene targets is also relevant for each case scenario.

\section{Potential pests to target with this SIGS}

The spray of RNAi can become a tool to control tropical pathogens, especially if there is a proven model or genomic information available. For example, Phytophtora infestans in potato (McLoughlin et al., 2018a), Fusarium oxysporum in banana (Mumbanza et al., 2013), and coffee rust Hemileia vastatrix (Cristancho et al., 2014). In the case of F. oxysporum, targeting the pathogenicity genes such as FMK1 and SNF1 that are related to root penetration, and others such as FRP1, XInR, FOW2, SGE1, and SIX, results in non-pathogenic strains at all (Thatcher et al., 2016). Otherwise, targeting the host genes such as AF2 and PRX33 that are related to the susceptibility to $F$. oxysporum, could also represent a strategy in the future (Lyons et al., 2015). In the case of coffee rust, the model works in wheat rust Puccinia striiformis f. sp. tritici genes PtMAPK1, PtCYC1, and PtCNB, which could be used as RNAi targets as well (Panwar et al., 2013). 


\section{Conclusion}

Achieving novel technologies, such as spray RNAi that can reduce the impact on the environment produced by farming, could be a sustainable solution for the high demand of food required for the future demography.

\section{References}

Allen, M. L., \& Walker, W. B. (2012). Saliva of Lygus lineolaris digests double stranded ribonucleic acids. Journal of Insect Physiology, 58(3), 391-396. https://doi.org/10.1016/j.jinsphys.2011.12.014

Axtell, M. J. (2013). Classification and comparison of small RNAs from plants. Annual Review of Plant Biology, 64(1), 137159. https://doi.org/10.1146/annurev-arplant-050312-120043

Bachman, P., Fischer, J., Song, Z., Urbanczyk-Wochniak, E., \& Watson, G. (2020). Environmental fate and dissipation of applied dsRNA in soil, aquatic systems, and plants. Frontiers in Plant Science, 11. https://doi.org/10.3389/fpls.2020.00021

Cai, Q., He, B., Kogel, K.-H., \& Jin, H. (2018a). Cross-kingdom RNA trafficking and environmental RNAi - natures blueprint for modern crop protection strategies. Curr Opin Microbiol, 46, 58-64. https://doi.org/doi:10.1016/j.mib.2018.02.003

Cai, Q., Qiao, L., Wang, M., He, B., Lin, F.-M., Palmquist, J., \& Jin, H. (2018b). Plants send small RNAs in extracellular vesicles to fungal pathogen to silence virulence genes. Science, 360, 1126-1129. https://doi.org/10.1126/science. aar4142

Castel, S. E., \& Martienssen, R. A. (2013). RNA interference in the nucleus: roles for small RNAs in transcription, epigenetics and beyond. Nature Reviews Genetics, 14, 100. https://doi.org/10.1038/nrg3355

Castillo-González, C., \& Zhang, X. (2018). The trojan horse of the plant kingdom. Cell Host and Microbe, 24(1), 1-3. https:// doi.org/10.1016/j.chom.2018.06.015

Charlton, W. L., Harel, H. Y. M., Bakhetia, M., Hibbard, J. K., Atkinson, H. J., \& McPherson, M. J. (2010). Additive effects of plant expressed double-stranded RNAs on root-knot nematode development. International Journal for Parasitology, 40(7), 855-864. https://doi.org/10.1016/j.ijpara.2010.01.003

Christiaens, O., Tardajos, M. G., Reyna, Z. L. M., Dash, M., Dubruel, P., \& Smagghe, G. (2018). Increased RNAi efficacy in Spodoptera exigua via the formulation of dsRNA with guanylated polymers. Frontiers in Physiology, 9(APR), 1-13. https://doi.org/10.3389/fphys.2018.00316

Cristancho, M. A., Botero-Rozo, D. O., Giraldo, W., Tabima, J., Riaño-Pachón, D. M., Escobar, C., Rozo, Y., Rivera, L. F., Durán, A., Restrepo, S., Eilam, T., Anikster, Y., \& Gaitán, A. L. (2014). Annotation of a hybrid partial genome of the coffee rust (Hemileia vastatrix) contributes to the gene repertoire catalog of the Pucciniales. Frontiers in Plant Science, 5, 1-11. https://doi.org/10.3389/fpls.2014.00594

Dhandapani, R. K., Gurusamy, D., Howell, J. L., \& Palli, S. R. (2019). Development of CS-TPP-dsRNA nanoparticles to enhance RNAi efficiency in the yellow fever mosquito, Aedes aegypti. Scientific Reports, 9(1), 1-11. https://doi. org/10.1038/s41598-019-45019-Z

Dubrovina, A. S., Aleynova, O. A., Kalachev, A. V., Suprun, A. R., Ogneva, Z. V., \& Kiselev, K. V. (2019). Induction of transgene suppression in plants via external application of synthetic dsRNA. International Journal of Molecular Sciences, 20(7), article 1585. https://doi.org/10.3390/ijms20071585 
Fanelli, E., Di Vito, M., Jones, J. T., \& De Giorgi, C. (2005). Analysis of chitin synthase function in a plant parasitic nematode, Meloidogyne artiellia, using RNAi. Gene, 349, 87-95. https://doi.org/10.1016/j.gene.2004.11.045

Fang, P. Y., Ramos, L. M. G., Holguin, S. Y., Hsiao, C., Bowman, J. C., Yang, H. W., \& Williams, L. D. (2017). Functional RNAs: Combined assembly and packaging in VLPs. Nucleic Acids Research, 45(6), 3519-3527. https://doi. org/10.1093/nar/gkw1154

Food and Agricultural Organization. (2014). SAFA: Sustainable Assessment of Food and Agriculture Systems Guidelines. http:// www.fao.org/3/a-i4113e.pdf

Fire, A., Xu, S., Montgomery, M. K., Kostas, S. A., Driver, S. E., \& Mello, C. C. (1998). Potent and specific genetic interference by double-stranded RNA in Caenorhabditis elegans. Nature, 391(6669), 806-811. https://doi.org/10.1038/35888

Gonsalves, D., Gonsalves, C., Ferreira, C., \& Fitch, M. (2010). Transgenic virus-resistant papaya: From hope to reality in controlling papaya ringspot virus in Hawaii. APSnet. https://oregonstate.edu/instruct/bi430-fs430/Documents2004/3B-BIOTECH\%20METH/Gonsalves-papaya-story-AmPhytopSoc2004.pdf

Guan, R. B., Li, H. C., Fan, Y. J., Hu, S. R., Christiaens, O., Smagghe, G., \& Miao, X. X. (2018). A nuclease specific to lepidopteran insects suppresses RNAi. Journal of Biological Chemistry, 293(16), 6011-6021. https://doi.org/10.1074/ jbc.RA117.001553

Guo, Q., Liu, Q., Smith, N. A., Liang, G., \& Wang, M.-B. (2016). RNA silencing in plants: Mechanisms, technologies and applications in horticultural crops. Current Genomics, 17(6), 476-489. https://doi.org/10.2174/13892029176661605 20103117

Haegeman, A., Vanholme, B., \& Gheysen, G. (2009). Characterization of a putative endoxylanase in the migratory plantparasitic nematode Radopholus similis. Molecular Plant Pathology, 10(3), 389-401. https://doi.org/10.1111/j.13643703.2009.00539.x

Höfle, L., Biedenkopf, D., Werner, B. T., Shrestha, A., Jelonek, L., \& Koch, A. (2020). Study on the efficiency of dsRNAs with increasing length in RNA-based silencing of the Fusarium CYP51 genes. RNA Biology, 17(4), 463-473. https://doi. org/10.1080/15476286.2019.1700033

Hou, Y., Zhai, Y., Feng, L., Karimi, H. Z., Rutter, B. D., Zeng, L., Choi, D. S., Zhang, B., Gu, W., Chen, X., Ye, W., Innes, R. W., Zhai, J., \& Ma, W. (2019). A Phytophthora effector suppresses trans-kingdom RNAi to promote disease susceptibility. Cell Host and Microbe, 25(1), 153-165. https://doi.org/10.1016/j.chom.2018.11.007

Hudzik, C., Hou, Y., Ma, W., \& Axtell, M. J. (2020). Exchange of small regulatory rnas between plants and their pests. Plant Physiology, 182(1), 51-62. https://doi.org/10.1104/pp.19.00931

Kaur, A., Kumar, A., \& Reddy, S. (2016). RNA Interference (RNAi) and Its Role in Crop Improvement: A Review. In M. Anis, \& N. Ahmad, Plant tissue culture: Propagation, conservation and crop improvement (pp. 379-394). Springer, Sigapore. https://doi.org/10.1007/978-981-10-1917-3_16

Kimber, M. J., McKinney, S., McMaster, S., Day, T. A., Fleming, C. C., \& Maule, A. G. (2007). flp gene disruption in a parasitic nematode reveals motor dysfunction and unusual neuronal sensitivity to RNA interference. The FASEB Journal, 21(4), 1233-1243. https://doi.org/10.1096/fj.06-7343com

Koch, A., Biedenkopf, D., Furch, A., Weber, L., Rossbach, O., Abdellatef, E., Linicus, L., Johannsmeier, J., Jelonek, L., Goesmann, A., Cardoza, V., McMillan, J., Mentzel, T., \& Kogel, K. H. (2016). An RNAi-Based control of Fusarium 
graminearum infections through spraying of long dsRNAs involves a plant passage and is controlled by the fungal silencing machinery. PLoS Pathogens, 12(10), Article 1005901. https://doi.org/10.1371/journal.ppat.1005901

Koch, A., \& Kogel, K. H. (2014). New wind in the sails: Improving the agronomic value of crop plants through RNAi-mediated gene silencing. Plant Biotechnology Journal, 12(7), 821-831. https://doi.org/10.1111/pbi.12226

Latruffe, L., Diazabakana, A., Bockstaller, C., Desjeux, Y., Finn, J., Kelly, E., Ryan, M., \& Uthes, S. (2017). Measurement of sustainability in agriculture: a review of indicators. Studies in Agricultural Economics, 118(3), 123-130. https://doi. $\operatorname{org} / 10.7896 / \mathrm{j} .1624$

Lebacq, T., Baret, P. V., \& Stilmant, D. (2013). Sustainability indicators for livestock farming. A review. Agronomy for Sustainable Development, 33(2), 311-327. https://doi.org/10.1007/s13593-012-0121-x

Lilley, C. J., Davies, L. J., \& Urwin, P. E. (2012). RNA interference in plant parasitic nematodes: a summary of the current status. Parasitology, 139(5), 630-640. https://doi.org/10.1017/S0031182011002071

Lyons, R., Stiller, J., Powell, J., Rusu, A., Manners, J. M., \& Kazan, K. (2015). Fusarium oxysporum triggers tissue-specific transcriptional reprogramming in Arabidopsis thaliana. PLoS ONE, 10(4), Article 121902. https://doi.org/10.1371/ journal.pone. 0121902

Mat-Jalaluddin, N. S., Othman, R. Y., \& Harikrishna, J. A. (2019). Global trends in research and commercialization of exogenous and endogenous RNAi technologies for crops. Critical Reviews in Biotechnology, 39(1), 67-78. https:// doi.org/10.1080/07388551.2018.1496064

McLoughlin, A. G., Walker, P. L., Wytinck, N., Sullivan, D. S., Whyard, S., \& Belmonte, M. F. (2018a). Developing new RNA interference technologies to control fungal pathogens. Canadian Journal of Plant Pathology, 40(3), 325-335. https:// doi.org/10.1080/07060661.2018.1495268

McLoughlin, A. G., Wytinck, N., Walker, P. L., Girard, I. J., Rashid, K. Y., De Kievit, T., Fernando, W. G. D., Whyard, S., \& Belmonte, M. F. (2018b). Identification and application of exogenous dsRNA confers plant protection against Sclerotinia sclerotiorum and Botrytis cinerea. Scientific Reports, 8(1), 1-14. https://doi.org/10.1038/s41598-01825434-4

Miller, S. C., Miyata, K., Brown, S. J., \& Tomoyasu, Y. (2012). Dissecting Systemic RNA Interference in the Red Flour Beetle Tribolium castaneum: Parameters Affecting the Efficiency of RNAi. PLoS ONE, 7(10), Article 47431. https://doi. org/10.1371/journal.pone.0047431

Mitter, N., Worrall, E. A., Robinson, K. E., Li, P., Jain, R. G., Taochy, C., Fletcher, S. J., Carroll, B. J., Lu, G. Q., \& Xu, Z. P. (2017). Clay nanosheets for topical delivery of RNAi for sustained protection against plant viruses. Nature Plants, 3 , Article 16207. https://doi.org/10.1038/nplants.2016.207

Mumbanza, F. M., Kiggundu, A., Tusiime, G., Tushemereirwe, W. K., Niblett, C., \& Bailey, A. (2013). In vitro antifungal activity of synthetic dsRNA molecules against two pathogens of banana, Fusarium oxysporum f. sp. cubense and Mycosphaerella fijiensis. Pest Management Science, 69(10), 1155-1162. https://doi.org/10.1002/ps.3480

Muthamilarasan, M., \& Prasad, M. (2013). Plant innate immunity: An updated insight into defense mechanism. Journal of Biosciences, 38(2), 433-449. https://doi.org/10.1007/s12038-013-9302-2

Mutti, N. S., Park, Y., Reese, J. C., \& Reeck, G. R. (2006). RNAi knockdown of a salivary transcript leading to lethality in the pea aphid, Acyrthosiphon pisum. Journal of Insect Science, 6, 3-9. https://doi.org/10.1673/031.006.3801 
Mysore, K., Flannery, E. M., Tomchaney, M., Severson, D. W., \& Duman-Scheel, M. (2013). Disruption of Aedes aegypti Olfactory System Development through Chitosan/siRNA Nanoparticle Targeting of semaphorin-1a. PLoS Neglected Tropical Diseases, 7(5), Article 2215. https://doi.org/10.1371/journal.pntd.0002215

Niehl, A., Soininen, M., Poranen, M. M., \& Heinlein, M. (2018). Synthetic biology approach for plant protection using dsRNA. Plant Biotechnology Journal, 16(9), 1679-1687. https://doi.org/10.1111/pbi.12904

Nunes, C. C., \& Dean, R. A. (2012). Host-induced gene silencing: A tool for understanding fungal host interaction and for developing novel disease control strategies. Molecular Plant Pathology, 13(5), 519-529. https://doi.org/10.1111/ j.1364-3703.2011.00766.x

Panwar, V., McCallum, B., \& Bakkeren, G. (2013). Endogenous silencing of Puccinia triticina pathogenicity genes through in planta-expressed sequences leads to the suppression of rust diseases on wheat. Plant Journal, 73(3), 521-532. https:// doi.org/10.1111/tpj.12047

Papp, I., Mette, M. F., \& Al., E. (2003). Evidence for nuclear Ppocessing of plant micro RNA and and short interfering RNA precursors. Plant Physiology, 132(3), 1382-1390. https://doi.org/10.1104/pp.103.021980

Parker, K. M., Barragán Borrero, V., Van Leeuwen, D. M., Lever, M. A., Mateescu, B., \& Sander, M. (2019). Environmental fate of RNA interference pesticides: Adsorption and degradation of double-stranded RNA molecules in agricultural soils. Environmental Science and Technology, 53(6), 3027-3036. https://doi.org/10.1021/acs.est.8b05576

Reagan, B. C., Ganusova, E. E., Fernandez, J. C., McCray, T. N., \& Burch-Smith, T. M. (2018). RNA on the move: The plasmodesmata perspective. Plant Science, 275, 1-10. https://doi.org/10.1016/j.plantsci.2018.07.001

Rodrigues, T. B., \& Petrick, J. S. (2020). Safety Considerations for humans and other vertebrates regarding agricultural uses of externally applied RNA molecules. Frontiers in Plant Science, 11, Article 407. https://doi.org/10.3389/fpls.2020.00407

Rosa, C., Kuo, Y.-W., Wuriyanghan, H., \& Falk, B. W. (2018). RNA interference mechanisms and applications in plant pathology. Annual Review of Phytopathology, 56(1), 581-610. https://doi.org/10.1146/annurev-phyto-080417-050044

Rutter, B. D., \& Innes, R. W. (2018). Extracellular vesicles as key mediators of plant-microbe interactions. Current Opinion in Plant Biology, 44, 16-22. https://doi.org/10.1016/j.pbi.2018.01.008

Schindler, J., Graef, F., \& König, H. J. (2015). Methods to assess farming sustainability in developing countries. A review. Agronomy for Sustainable Development, 35(3), 1043-1057. https://doi.org/10.1007/s 13593-015-0305-2

Song, X. S., Gu, K. X., Duan, X. X., Xiao, X. M., Hou, Y. P., Duan, Y. B., Wang, J. X., Yu, N., \& Zhou, M. G. (2018). Secondary amplification of siRNA machinery limits the application of spray-induced gene silencing. Molecular Plant Pathology, 9(12), 4543-4560. https://doi.org/10.1111/mpp.12728

Thatcher,L.F., Kidd, B. N., \& Kazan, K. (2016). Belowground defence strategies in plants. Springer. https://doi.org/10.1007/9783-319-42319-7

The Nobel Prize in Physiology or Medicine. 2006. NobelPrize.org. Nobel Media AB 2020. Thu. 3 Dec 2020. https://www. nobelprize.org/prizes/medicine/2006/summary/

Wang, M., \& Jin, H. (2017). Spray-Induced Gene Silencing: a Powerful Innovative Strategy for Crop Protection. Trends in Microbiology, 25(1), 4-6. https://doi.org/10.1016/j.tim.2016.11.011

Wang, K., Peng, Y., Pu, J., Fu, W., Wang, J., \& Han, Z. (2016a). Variation in RNAi efficacy among insect species is attributable to dsRNA degradation in vivo. Insect Biochemistry and Molecular Biology, 77, 1-9. https://doi.org/10.1016/j. ibmb.2016.07.007 
Wang, M., Weiberg, A., Lin, F., Thomma, B., Huang, H., \& Jin, H. (2016b). Bidirectional cross-kingdom RNAi and fungal uptake of external RNAs confer plant protection. Nature Plants, 2, Article 16151. https://doi.org/doi:10.1038/ nplants.2016.151

Wang, Y., Zhang, H., Li, H., \& Miao, X. (2011). Second-generation sequencing supply an effective way to screen RNAi targets in large scale for potential application in pest insect control. PLOS ONE, 6(4), Article 18644. https://doi.org/10.1371/ journal.pone. 0018644

Waterhouse, P. M., \& Fusaro, A. F. (2006). Viruses Face a Double Defense by Plant Small RNAs. Science, 313(5783), 54-55. https://doi.org/10.1126/science.1130818

Weiberg, A., Wang, M., Lin, F. M., Zhao, H., Zhang, Z., Kaloshian, I., Huang, H. D., Jin, H., Khaloshian, I., Huang, H. D., \& Jin, H. (2014). Fungal small RNAs suppress plant immunity by hijacking host. Science, 342(6154), 118-123. https:// doi.org/10.1126/science. 1239705

Wilson, R. C., \& Doudna, J. A. (2013). Molecular mechanisms of RNA interference. Annual Review of Biophysics, 42(1), 217-239. https://doi.org/10.1146/annurev-biophys-083012-130404

Yoon, J.-S., Mogilicherla, K., Gurusamy, D., Chen, X., Chereddy, S. C. R. R., \& Palli, S. R. (2018). Double-stranded RNA binding protein, Staufen, is required for the initiation of RNAi in coleopteran insects. Proceedings of the National Academy of Sciences, 115(33), 8334-8339. https://doi.org/10.1073/pnas.1809381115

Yu, N., Christiaens, O., Liu, J., Niu, J., Cappelle, K., Caccia, S., Huvenne, H., \& Smagghe, G. (2013). Delivery of dsRNA for RNAi in insects: An overview and future directions. Insect Science, 20(1), 4-14. https://doi.org/10.1111/j.17447917.2012.01534.x

Yu, X. D., Liu, Z. C., Huang, S. L., Chen, Z. Q., Sun, Y. W., Duan, P. F., Ma, Y. Z., \& Xia, L. Q. (2016). RNAi-mediated plant protection against aphids. Pest Management Science, 72(6), 1090-1098. https://doi.org/10.1002/ps.4258

Zhang, T., Zhao, Y. L., Zhao, J. H., Wang, S., Jin, Y., Chen, Z. Q., Fang, Y. Y., Hua, C. L., Ding, S. W., \& Guo, H. S. (2016). Cotton plants export microRNAs to inhibit virulence gene expression in a fungal pathogen. Nature Plants, 2, Article 16153. https://doi.org/10.1038/nplants .2016.153.

Zhang, Y., Fan, J., Sun, Jing-rui, \& Chen, J. (2015). Cloning and RNA interference analysis of the salivary protein C002 gene in Schizaphis graminum. Journal of Integrative Agriculture, 14(4), 698-705. https://doi.org/10.1016/S20953119(14)60822-4

Zhao, Y., Liang, X., \& Zhou, J.-M. (2018). Small RNA trafficking at the forefront of plant-pathogen interactions. F1000Research, 7, Article 1633. https://doi.org/10.12688/f1000research.15761.1 